Frontier Figures 


\section{CALIFORNIA STUDIES IN 20TH-CENTURY MUSIC}

Richard Taruskin, General Editor

1. Revealing Masks: Exotic Influences and Ritualized Performance in Modernist Music Theater, by W. Anthony Sheppard

2. Russian Opera and the Symbolist Movement, by Simon Morrison

3. German Modernism: Music and the Arts, by Walter Frisch

4. New Music, New Allies: American Experimental Music in West Germany from the Zero Hour to Reunification, by Amy Beal

5. Bartók, Hungary, and the Renewal of Tradition: Case Studies in the Intersection of Modernity and Nationality, by David E. Schneider

6. Classic Chic: Music, Fashion, and Modernism, by Mary E. Davis

7. Music Divided: Bartók's Legacy in Cold War Culture, by Danielle Fosler-Lussier

8. Jewish Identities: Nationalism, Racism, and Utopianism in Twentieth-Century Art Music, by Klára Móricz

9. Brecht at the Opera, by Joy H. Calico

10. Beautiful Monsters: Imagining the Classic in Musical Media, by Michael Long

11. Experimentalism Otherwise: The New York Avant-Garde and Its Limits, by Benjamin Piekut

12. Music and the Elusive Revolution: Cultural Politics and Political Culture in France, 1968-1981, by Eric Drott

13. Music and Politics in San Francisco: From the 1906 Quake to the Second World War, by Leta E. Miller

14. Frontier Figures: American Music and the Mythology of the American West, by Beth E. Levy 


\title{
Frontier Figures
}

American Music and the Mythology

of the American West

\author{
Beth E. Levy
}

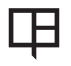

UNIVERSITY OF CALIFORNIA PRESS

Berkeley Los Angeles London 
University of California Press, one of the most distinguished university presses in the United States, enriches lives around the world by advancing scholarship in the humanities, social sciences, and natural sciences. Its activities are supported by the UC Press Foundation and by philanthropic contributions from individuals and institutions. For more information, visit www.ucpress.edu.

University of California Press

Berkeley and Los Angeles, California

University of California Press, Ltd.

London, England

(C) 2012 by The Regents of the University of California

Library of Congress Cataloging-in-Publication Data

Levy, Beth E. (Beth Ellen), 1972-

Frontier figures : American music and the mythology of the American West / Beth E. Levy. - 1st ed.

p. $\quad \mathrm{cm} .-$ (California studies in 2oth-century music;14)

Includes bibliographical references and index.

ISBN 978-0-520-26776-3 (cloth : alk. paper) - ISBN 978-0-520-26778-7 (pbk. : alk. paper)

1. Music-United States-2oth century-History and criticism.

2. Legends-West (U.S.) - History and criticism. 3. West (U.S.) Social life and customs - 2oth century. 4. West (U.S.)-History1890-1945. I. Title.

ML200.5.L49 2012

$781.5^{\prime} 9-\mathrm{dc} 23$

2011038214

Manufactured in the United States of America
$\begin{array}{llllllllll}20 & 19 & 18 & 17 & 16 & 15 & 14 & 13 & 12 & 11\end{array}$
$\begin{array}{llllllllll}10 & 9 & 8 & 7 & 6 & 5 & 4 & 3 & 2 & 1\end{array}$

In keeping with a commitment to support environmentally responsible and sustainable printing practices, UC Press has printed this book on 50-pound Enterprise, a 30\% post-consumer-waste, recycled, deinked fiber that is processed chlorine-free. It is acid-free and meets all ansi/ NISO (z 39.48) requirements. 
To my parents,

David and Lynne Levy 
